\title{
Promoting moral and democratic competencies: towards an educational turn of Bioethics
}

Aluisio Serodio ${ }^{1}$, Benjamin I. Kopelman ${ }^{2}$, Patricia U.R. Bataglia ${ }^{3}$

\begin{abstract}
The purpose of this paper is to present Bioethics, particularly its educational aspect, as a way to promote moral and democratic competencies, thus improving a personal capacity to face not only bioethical issues but also broader ethical, moral and even political problems. We believe that we should invest educative efforts on the affective and cognitive aspects of moral behavior if we want to promote the capacity to make moral judgments and act according to them. In pluralistic democratic societies, it is necessary to also promote the capacity to speak up and listen to arguments as a means to deal with moral problems. Any Bioethics which does not also include an educational action is prone to lose most of its significance. We propose that Bioethics should be led to an educational turn, focusing on the construction of an educative toolbox composed of interventional and evaluative instruments.
\end{abstract}

Keywords: Bioethics. Education. Moral development. Democracy.

\section{Resumo}

\section{A promoção das competências moral e democrática: por uma virada educacional da Bioética}

O propósito deste artigo é apresentar a Bioética, especialmente em seu recorte educacional, como meio para a promoção das competências moral e democrática, estimulando a capacidade para enfrentar não apenas os temas bioéticos, mas também problemas éticos, morais e políticos em geral. Acreditamos que esforços educativos devam ser dirigidos aos aspectos afetivo e cognitivo do comportamento moral se quisermos promover a capacidade de fazer juízos morais e agir de acordo com tais juízos. Em sociedades pluralistas democráticas, é necessário também promover habilidades de expressão e de escuta como um meio para lidar com problemas morais. Qualquer Bioética que não seja também um ato educacional está fadada a perder muito do seu significado. Propomos uma virada educacional da Bioética, com foco na construção de uma caixa de ferramentas educacionais composta por instrumentos de intervenção e avaliação.

Palavras-chave: Bioética. Educação. Desenvolvimento moral. Democracia.

\section{Resumen}

\section{La promoción de la competencia moral y democrática: por un giro educacional de la Bioética}

El propósito del artículo es presentar la Bioética, especialmente en su recorte educacional, como un medio de promover la competencia moral y democrática, desarrollando la capacidad para enfrentar no solamente los temas bioéticos sino también problemas éticos, morales y políticos en general. Creemos que diversos esfuerzos educativos deben ser dirigidos a los aspectos afectivos y cognitivos del comportamiento moral si queremos desarrollar la capacidad de hacer juicios morales y de actuar de acuerdo con tales juicios. En sociedades pluralistas democráticas es necesario también promover habilidades de expresión y escucha como medio para lidiar con problemas morales. Cualquier Bioética que no sea también un acto educacional está destinada a perder mucho de su significado. Proponemos un giro educativo de la Bioética, enfocado en la construcción de una caja de herramientas educacionales compuesta por instrumentos de intervención y evaluación.

Palabras clave: Bioética. Educación. Desarrollo moral. Democracia.

1.Ph.D. lulabra@yahoo.com - Universidade Federal de São Paulo (Unifesp), São Paulo/SP 2. Ph.D. bkopelman@terra.com.br - Unifesp, São Paulo/SP 3. Ph.D. patriciaurbataglia@gmail.com - Universidade Estadual Paulista Júlio de Mesquita Filho (Unesp), Marília/SP, Brasil.

Correspondência

Aluisio Serodio - R. Borges Lagoa, 1.065, cj 115 CEP 04038-032. São Paulo/SP, Brasil.

Declaram não haver conflitos de interesse. 
It is estimated that in a single evening, on June $20^{\text {th }} 2013$, more than $1,000,000$ people took to the streets of several Brazilian cities. These huge demonstrations were preceded and succeeded by smaller ones and at least three characteristics were common to all of them: 1) They were organized through online social networks and lacked traditional unified leadership; 2) Even though their claims were multiple, one primary target was selected: the quality of public services (especially transportation, healthcare, education and security); and 3) There was frustration regarding the way democratic representation was conducted in the country. It is our understanding that this last characteristic suggests some demands which might be addressed by Bioethics.

As we have seen in the recent past with somewhat similar popular movements (Occupy Wall Street, Spanish demonstrations and the Arab Spring, for example), both analysts and the government seemed to be completely at a loss regarding the significance, the proper answer and the foreseeable consequences regarding the voice of the people. In a typical example of what Bauman calls "liquid modernity", uncertainty was all around ${ }^{1}$.

According to this conception, contemporary western societies are still modern. The denomination of post-modernity is not well founded, since it suggests the idea that we have overtaken Modernity, while, in fact, we keep living based on its main constitutive elements: its dynamic of permanent rational questioning and its framework, in which social positions are conquered through merit instead of being a birthright ${ }^{2}$.

But current modernity is quite different from the one illuminist philosophers had imagined. In the $20^{\text {th }}$ century, with the emergence of totalitarian regimes on both sides of the political spectrum and after two world wars (when more people were killed or abandoned to die as a result of human decisions than any other period of history) ${ }^{3}$, the belief that rational inquiry would lead us to a world of peace and prosperity for all could not be sustained anymore. Ideological utopias (fascism, communism, positivism) were severely shaken. Contemporary western societies gradually lost their faith in militancy and political passions to end up consecrating a hedonistic individualism ${ }^{4}$.

Moreover, our times are "liquid", in the sense that things are always flowing, taking different forms that are not easily contained ${ }^{1}$. With the arrival of the digital revolution and economic globalization, this continuous movement was impressively accelerated, and both the physical world and human relationships, seem to run in faster cycles. As expected, this accelerated ongoing change has also affected ethics and morality.

John Rawls raised a question that clearly enunciates the challenge, which is both ethical and political, that we have to face: How is it possible that there may exist over time a stable and just society offree and equal citizens profoundly divided by reasonable though incompatible religious, philosophical and moral doctrines $?^{5}$ Complexity reaches its peak in developing countries, where the task of stabilizing a just society has to be preceded by the necessity of promoting freedom and equality among its citizens.

Under all those circumstances, one thing is paramount: the need to capacitate people to engage in discussions regarding propositions intended to solve contemporary social problems. The purpose of this article is to present Bioethics, particularly its educational aspect, as a way to promote competencies related to practical reasoning and moral action, thus improving personal skills, which are necessary to understand and participate in upcoming approaches of deliberative democracy.

\section{Practical problems}

One thing that political and moral philosophies have in common is that they deal with practical problems. These are problems which must be solved, otherwise ordinary life will be disturbed with consequences that are, at the very least, unpleasant. Human things, especially human relationships, give birth to practical problems. These things and relationships are marked by contingency: they do not follow any law of necessity and, therefore, can be different from what they happen to be. Because of that, whenever one faces practical problems, one needs a form of knowledge that does not lead to certainty; but will, nevertheless, produce recommendations, guidance or obligations ${ }^{6}$.

There are three kinds of practical problems: pragmatic, ethical and moral ${ }^{7}$. Pragmatic problems deal with situations in which the final goal is already established. The agent has to find out, based on instrumental reasoning and empirical observation, efficient ways to accomplish that goal ${ }^{7}$.

Ethical practical problems are related to the choice of goals ${ }^{7}$. They explore the category of values or goods, things considered worthy by the agent. Their central point is to find out or to build an authentic conception of a good life, a life worth living, which is the most legitimate of all individual 
enterprises: the search for happiness or, as the ancient Greeks would say, eudaimonia. In order to pursue that, it is necessary to have enlightenment and self-knowledge, which might be promoted by means of individual reflexive processes ${ }^{7}$.

Moral practical problems emerge from conflicts between different views of what constitutes a good life. Their central point is the justification and application of rules which establish reciprocal duties. Basically, moral problems are related to justice in interpersonal relationships, and this implies that agents should be able to put themselves in someone else's shoes and understand different world views. To accomplish that, individual reflexive thought is not enough: only through open and free discussions, in which communicative reasoning (reasoning that aims at comprehension rather than at manipulation and control) is employed, can just resolutions be achieved ${ }^{7}$.

Whenever these conflicts of needs and interests involve broad groups (such as the members of a city, a nation or even of the entire world), they may be described as political problems. In our view, since Bioethics deals with ethical, moral and political problems in the fields of biological sciences and healthcare, it might be a powerful tool in the endeavor of capacitating people to face contemporary pluralistic societies' practical problems.

\section{Promoting moral competence}

In the field of moral psychology, there is some agreement on the fact that moral behavior has two different, though inseparable, aspects: affect and cognition. To some extent, the context in which moral decisions are made and moral actions are performed influences these two aspects of moral behavior. While some authors stress the importance of feelings and emotions, others will emphasize rationality, and yet another group will focus on the socio-historical context.

An example of the last group is the social learning trend, which associates moral education to the observance and imitation of examples offered by relevant social roleplayers $^{8}$. Even though this traditional approach is considered by many as the most efficacious means of teaching and learning moral behavior, it has some pitfalls. The most obvious one is that the models could be either good or bad and, thus, the simple imitation of relevant examples may lead people astray. Nevertheless, it is indeed a powerful way to influence moral behavior and, therefore, it will always be an important part of any educative approach to moral development to invest some effort on relevant social roleplayers' awareness and preparation in this area.

The social-intuitionist trend is among the first group. It believes that when one faces a moral problem one simply feels - based on emotions, intuition, and culture - the best course of action. Reasoning would follow in order to justify one's intuitive decision and/or to influence someone else's judgment. According to this view, people would reason as a lawyer trying to defend their intuitive position rather than as a judge trying to find out the correct decision ${ }^{9}$. Even though social-intuitionism recently developed an evaluative instrument based on its theoretical understanding of morality ${ }^{10}$, it still lacks a consistent body of empirical evidence to corroborate its vision.

Among rationalists, the cognitive-structural trend - by far the most empirically corroborated trend in moral psychology - defends the idea that affect is the source of energy for moral action. Affect would provide the stuff of moral ideals and moral orientation, thus motivating moral behavior ${ }^{11}$. Cognition, on the other hand, would lead this motivation towards decisive action; and it would have the function of applying moral ideals to specific situations in an organized and coherent way ${ }^{12}$.

Lawrence Kohlberg, the main author of the cognitive-structural trend, once defined the cognitive aspect as a competence, i.e., a capacity, skill or ability to perform something efficiently. According to him, moral judgment competence is the capacity to make decisions and judgments which are moral (i.e., based on internal principles) and to act in accordance with such judgments ${ }^{13}$.

Nomatter the trend one chooses as a theoretical reference, it is unequivocal that we live in a time of motivational deficit when it comes to accomplishing moral actions. When Modernity reaffirms individual autonomy, it uncouples moral behavior from both divine salvation and secular conceptions of a good life, thus causing a motivational deficit. After all, why should one act fairly if it will neither help one's own life plan (sometimes it may actually jeopardize this plan), nor lead one to paradise?

Moral motivation is defined as the capacity to confer priority to moral values over other kinds of values (economic, social, aesthetic, etc.) whenever the agent faces a practical problem ${ }^{14}$. It means that moral values (such as freedom, honesty and 
justice) occupy the highest positions in a personal hierarchy of values. And since values are an affective investment, the reason, by itself, does not seem capable of motivating people to act morally.

In figure 1 we set forth a diagram, based on the "Dual Aspect Theory of Moral Behavior and Development" 12 and on the concept of moral judgment competence ${ }^{13}$, which expresses our comprehension regarding what happens in the human mind whenever we face a practical ethical or moral problem. According to the above mentioned theory, moral judgment competence leads values and ideals through moral decision making and behavior. However, if we pay attention to the very definition of moral judgment competence, we learn that it is founded on "internal principles" which, meanwhile, might be understood as a reflexive abstraction of the affective aspect. It suggests that affect and cognition are reciprocally influencing each other throughout the process that results in moral behavior.

Figure 1. Moral competence. Elaboration on the "Dual Aspect Theory of Moral Behavior and Development" using the definition of "moral judgment competence"

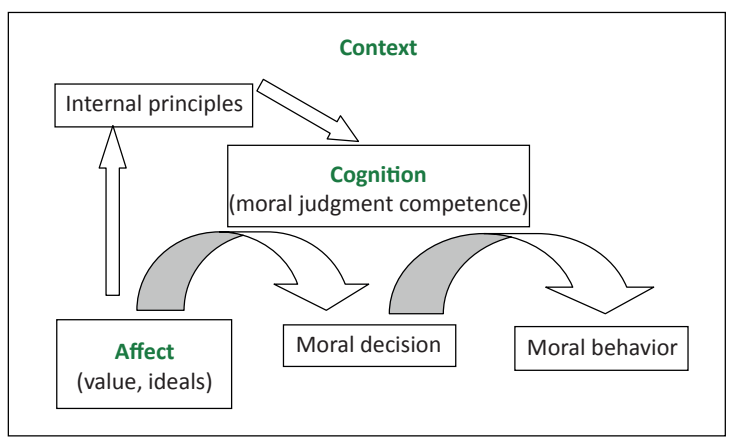

Neuroscience has already found evidence that corroborates a model according to which cognition and affect, thanks to their ongoing interaction, have to be balanced in order to promote moral behavior. Damasio observed that patients with brain damage in areas mainly responsible for emotional states, besides showing shallow emotional responses and uncaring behavior, also had trouble choosing the best course of action when facing a practical problem, despite otherwise intact cognitive capacities ${ }^{15}$. He concludes that emotionless reasoning may prevent individuals, either sick or healthy, from assigning different values to different options, exposing a flat decision-making landscape. The idea is that feelings and emotions, instead of only disturbing reason, can also support it: emotional impairment is an important source of irrational behavior ${ }^{15}$.
From an educational standpoint, since, on one hand, rearrangements of values and the consequent multiplicity of views of a good life are considered legitimate, and, on the other hand, there is growing evidence of a positive interaction between affect and cognition in the management of practical problems, it seems important to invest educational efforts in both aspects of moral behavior (as well as in the improvement of contextual conditions which could complicate or facilitate moral performance). In this sense, educative interventions should aim at promoting the precedence of moral values over other sorts of values and the capacitating of individuals to elaborate, expose and defend reasonable plans for a good life.

However, in contemporary pluralistic societies, promoting moral competence (in its affective and rational aspects) is not enough. In a world where views of a good life are so diversified, individual conscience and goodwill do not suffice to justify moral actions and moral rules. The Kantian monologic perspective of the individual conscience is forced to expand itself to a dialogic intersubjectivity. In this sense, the idea of democracy, translated from the political to the ethical realm, inspires the presentation of another competence, which is pivotal to deal with moral and political problems in our times.

\section{The idea of democracy: from politics to ethics}

The idea of democracy, as most of the ideas that constitute the western tradition, was conceived in ancient Greece. Basically, the "power of the people" was characterized by a regime of government in which decisions that concerned the polis (political decisions) were made by the whole citizenry, and not by a sovereign or any privileged group. Those decisions were the result of a process of discussion and deliberation, conducted in the public square (the agora) and open to all citizenswhich excluded women and slaves.

This was the procedure imagined by ancient Athenians to confer legitimacy to political decisions, since freedom of speech, equal opportunity of expression and a voting mechanism in which the vote of every citizen had the same weight, might transmute defeat into something more acceptable ${ }^{16}$.

But this form of direct democracy would be discontinued with the decline of the Greek civilization. Non-democratic decision making procedures prevailed all over the Middle Ages and 
only with Modernity were democratic procedures then different from the ones invented by the ancient Greeks (representation and inclusion of all interested were important historical changes) returned and eventually triumphant in western developed societies.

A democratic society goes beyond these procedural characteristics of a regime: it institutes rights that, among other things, protect reasonable minority world views against the will of the majority. Whenever popular sovereignty is exercised in a context of respect for all and takes into account the rights of minorities, democracy reveals itself as a moral concept ${ }^{17}$.

Agovernment regime's or a society's procedural relationship between democracy and politics implies a fundamental necessity: the empowerment of people to participate in political decisions. The promotion of this individual democratic competence is, at the same time, a necessity and a consequence of democratic participation. Thanks to its discursive nature, democratic participation can develop practical reasoning, tolerance and mutual respect, while simultaneously gaining self-knowledge and self-realization ${ }^{18}$.

We may define democratic competence as the capacity to enunciate ethical discourses and engage in moral discussions, using communicative reasoning in order to produce and accept arguments as a mean to solve ethical conflicts ${ }^{19}$. According to Dewey ${ }^{20}$, in order to enter the fields of ethics and morals, democracy cannot be understood only as something external and institutional, but also as a moral ideal, a value in the name of which people will act. The author has introduced the idea of democracy as a moral value when he stated that democracy (...) is a way of life, social and individual ${ }^{20}$.

From the individual standpoint, a democratic way of life represents one's freedom to plan one's own life and the capacity to execute this plan, utilizing cultural contributions to enrich it while taking into account its consequences to oneself and to others ${ }^{21}$. From the social standpoint, a democratic way of life might be described as a set of attitudes that includes the renunciation of self-righteousness, honest conversation and good manners ${ }^{16}$.

Indian pacifist Mahatma Gandhi perfectly posed the challenge we have to face: In true democracy every man and woman is taught to think for himself or herself. How this real revolution can be brought about I do not know (... ${ }^{22}$. We could not agree more with Gandhi's aim and we also share his doubt: how could we promote the paramount revolution of making each human being think for him or herself? Education for and by Bioethics may be one such way.

\section{Educating for Bioethics and educating by Bioethics}

We understand Bioethics not just as an academic interdisciplinary field where ethical conflicts in biological sciences and human healthcare are discussed, but mainly as a transcultural international movement which emerged from the cultural effervescence of the 1960s and from the necessity of an applied ethics related to contemporary uncertainties in biology and healthcare. Either as a social movement or as an academic field, we believe that Bioethics' main task is to share ethical enlightenment (providing information, propitiating discussion and reflection, improving the options for deliberation) and moral orientation (through revisable normative regulations) for the management of ethical and moral problems in the sciences of life and healthcare.

Because the fields of biological sciences and human healthcare are a typical example of the contemporary world's complexity and because their issues are of general interest (after all, human dignity is directly related to liberty and without appropriate health conditions we cannot talk about free human beings), we believe that Bioethics can instigate, at different levels of formal education, those competencies that would help people to face not only bioethical problems, but also more general current ethical, moral and even political problems.

In this sense, we foresee the contribution of Bioethics under two aspects: 1) Offering itself as a tolerant respectful locus of discussions, where different world views might peacefully interact in order to improve social life; and 2) Promoting, by means of educative interventions, moral and democratic competencies.

Education for Bioethics is a social need. Health is a central contemporary value and the capacity to insert it in any formulation of a good life is indispensable. Therefore, one ought to be competent to evaluate the justifications for the employment of new technological interventions in healthcare that one will sooner or later have to address. Because of that, it is important to promote a cognitive capacity that can lead moral values and ideals through decision making and action. But, 
in order to be able to do that, the agent should elaborate an ordained system of values in which moral values take precedence over other kinds of values - which implies a pedagogical exploration of affection, the motivational aspect of moral behavior.

But nowadays, particularly because of our choices' social impact, it is insufficient. In order to be considered legitimate in a democratic society, these choices cannot violate someone else's rights. Therefore, all choices which have some social impact will only gain legitimacy after being scrutinized and discussed. As a consequence, it is of the utmost importance to be capable not only to construct, expose and defend personal ideals of a good life, but also to listen, tolerate and - whenever it is possible - respect other people's ideals. All those capacities are explicit in the concepts of moral and democratic competencies.

The idea of education by Bioethics is inspired by Dewey's understanding of education by democracy ${ }^{20}$. The development of moral and democratic competencies is, at the same time, a necessity to face bioethical problems and a consequence of this enterprise. Besides being intellectually riveting, bioethical issues are individually and socially important. A creative exploration of a Bioethics' set of themes may capture and maintain people's attention, especially from adolescence onwards, in times when Liquid Modernity spreads plenty of information and individuals are surrounded by a large set of attractions.

\section{Towards an educational turn of Bioethics}

Bioethics has been an environment created and inhabited by specialists. Even assuming that they are prepared and well intentioned, could these specialists speak for others with legitimacy and reliability? This is a really difficult problem, particularly in regions where social disparities are enormous, as it is in Brazil: even if we managed to include all interested in the discussions with equal opportunity to participate, a strong imbalance in communicative capacity would still exist. Large groups (those socially more vulnerable) have trouble expressing their views. The alternative of finding representatives to speak for them is highly questionable.

For all that which was presented in this paper, we suggest that Bioethics should be led to an educational turn - the term "educational turn" is inspired by the term "linguistic turn", which is enshrined in $20^{\text {th }}$ century philosophical lexicon, meaning that philosophy should focus primarily on the relationship between itself and language. Any Bioethics which is not also an educational act is prone to lose most of its significance. It is troublesome to see bioethicists engaged in complicated discussions, diverging on points whose relevance is sometimes quite questionable and without noticing that, at the end, when they have eventually settled all those points, nothing would be really solved: men and women, who needed to be educated, would stay uninformed and impotent.

Surely, discussions on bioethical themes are useful in the search of consensus or agreement, but, if we intend to include all concerned, it is paramount to promote moral and democratic competencies on a large scale. Besides, it is through broad participation that any normative regulation on bioethical issues will gain legitimacy. Our understanding is that bioethicists from any line of thought should expose their ideas not only by aiming at conflict resolutions, but also - and mainly - with a pedagogical concern regarding clarifying problems and in a way that could help all interested with their choices.

This emphasis on education for and by Bioethics that we propose goes hand in hand with the notion of development as freedom presented by Amartya Sen ${ }^{23}$. According to him, development consists of the elimination of privations that limit individual choices and opportunities ${ }^{23}$. Therefore, besides searching for institutional improvement and justice in the distribution of social burdens and benefits, societies - especially developing world societies should understand development as a process of the expansion of liberty ${ }^{24}$. This is the profound sense of promoting moral and democratic competencies: enabling people to confer feasibility to things they consider worthy to do. This capacity is a form of freedom: the freedom to adopt different life styles ${ }^{23}$.

\section{Final considerations}

As we mentioned at the beginning of this article, democratic representation was one of the main targets of Brazilian demonstrations that took place on June 2013. In a moment when political parties are despised and politicians abhorred, it is likely that some form of direct democratic participation will gain importance. If this proves to be the case, the promotion of citizens' moral and democratic competencies will be more pivotal than ever.

Bearing in mind its origins as a social need for ethical enlightenment and moral orientation, 
the academic field of Bioethics could support the elaboration of a rather interesting educative toolbox to foster those competencies. This toolbox might contain a set of interventional and assessment instruments recollected from multicenter experiences which need not to be affiliated to a unique philosophical school or psychological trend.

In this sense, it is noteworthy that a Brazilian network of Bioethics' professors (Rede Brasileira de Professores de Bioética) is being organized and a meeting is scheduled for July, 2016. This is an example of how bioethicists might make themselves contactable in order to exchange teaching experiences. There are plenty of teaching tools that could be presented in meetings and workshops (methods for case discussion, employment of arts and literature to trigger evaluation of moral values, clips of movies etc.). When it comes to the issue of assessment, the Achilles' heel of ethics education, it is paramount to point out that the instruments available (such as the Moral Competence Test, The
Defining Issues Test, the Moral Judgment Interview, the Moral Foundations Questionnaire etc.) are useful only to assess the impact of some educational interventions on a group of participants' moral development; these tests must not be used in order to grade or select particular individuals.

It is our view that Bioethics should mean the sharing of the human condition and the improvement of social life. It could help people to meet the conditions not only for surviving, but also for actualizing life projects which are reasonable and compatible with others' similar projects ${ }^{25}$.

Finally, what we propose as an educational turn is that Bioethics should serve not just as a bridge to the future and between science and humanities (as Potter imagined when he created the neologism), but also as a bridge over the vast gap that separates the individual de jure from the individual de facto $^{1}$, an individual who is capable of imagining, constructing and defending, democratically, his or hers ideals of a good life.

\section{Referências}

1. Bauman Z. Liquid modernity. Malden: Polity Press; 2000.

2. Heller A. A Theory of modernity. Oxford: Wiley; 1999.

3. Hobsbawn E. The age of extremes. New York: Pantheon Books; 1995.

4. Lipovetsky G. Hypermodern times. Malden: Polity Press; 2005.

5. Rawls J. Political liberalism. New York: Columbia University Press; 2005.

6. Canto-Sperber M, Ogien R. Pratique. In: Canto-Sperber M, editor. Dictionnaire d'éthique et de philosophie moral. Paris: Presses Universitaires de France; 2004. p. 1524-34.

7. Habermas J. On the pragmatic, the ethical and the moral employments of practical reason. Justification and application: remarks on discourse ethics. Cambridge: The MIT Press; 1993. p. 1-18.

8. Bandura A. Social learning theory. New York: General Learning Press; 1971.

9. Haidt J. The emotional dog and its rational tail: a social intuitionist approach to moral judgment. Psychol Rev. 2001;108(4):814-34.

10. Graham J, Nosek BA, Haidt J, Iyer R, Koleva S, Ditto PH. Mapping the moral domain. Journal of Personality and Social Psychology. 2011;101(2):366-85.

11. Piaget J. Six psychological studies. New York: Vintage Books; 1968.

12. Lind G. La moral puede enseñarse: manual teórico-practico de la formación moral y democrática. Ciudad de Mexico: Trillas; 2007.

13. Kohlberg L. Development of moral character and moral ideology. In: Hoffman ML, Hoffman LW, editors. Review of Child Development Research. New York: Russell Sage Foundation; 1964. p. 381-431.

14. Rest JR. Background: theory and research. In: Rest JR, Narváez D, editors. Moral development in the professions: psychology and applied ethics. Hillsdale: Lawrence Erlbaum Associates; 1994. p. 1-26.

15. Damasio A. Descartes' error. New York: Penguin Books; 2005.

16. Ribeiro RJ. Democracia. São Paulo: Publifolha; 2001.

17. Larmore C. The moral basis of political liberalism. Journal of Philosophy. 1999;96(12):599-625.

18. Warren ME. The self in discursive democracy. In: White KS, editor. The Cambridge companion to Habermas. Cambridge: Cambridge University Press; 1995. p. 167-200.

19. Lind G. Teaching students to speak up and listen to others: fostering moral-democratic competencies. In: Lund DE, Carr PR, editors. Doing democracy: striving for political literacy and social justice. New York: Peter Lang; 2008. p. 319-36.

20. Dewey J. Problems of men. New York: Philosophical Library; 1946. p. 57.

21. Aikin WM. The story of the eight-year study. London: Harper; 1942. v. 1. (Adventures in American education) 
22. Gandhi M. Essence of democracy. In: Prabhu RK, Rao UR, editors. The mind of Mahatma Gandhi. [Internet]. 1960 [acesso 14 maio 2013]. Disponível: http://bit.ly/299ehpm

23. Sen A. Development as freedom. New York: Oxford University Press; 1999.

24. Sen A. The idea of justice. Cambridge: Harvard University Press; 2009.

25. Schramm FR. Bioética sem universalidade? Justificação de uma bioética latinoamericana e caribenha de proteção. In: Garrafa V, Kottow M, Saada A, editors. Bases conceituais da bioética: enfoque latino-americano. São Paulo: Gaia; 2006. p. 143-57.

\section{Participation of the authors}

This article was based on the doctoral thesis of the lead author, Aluisio Serodio, whose work was supervised by co-authors, Benjamin I. Kopelman and Patricia U. Bataglia. All authors participated in the planning of this article. The final draft was made by the main author and the manuscript was reviewed, corrected and approved by the co-authors.

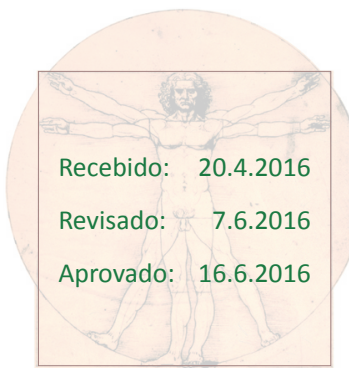

